\title{
Effect of irrigatation, rainfed conditions and nitrogen sources on newly released upland rice cultivar (BRS Esmeralda) with greater tolerance to drought stress
}

\author{
Amanda Ribeiro Peres ${ }^{1 *}$, Ricardo Antônio Ferreira Rodrigues ${ }^{1}$, José Roberto Portugal ${ }^{2}$, Orivaldo Arf ${ }^{2}$, Alex \\ Rangel Gonzaga ${ }^{2}$, Flávia Constatino Meirelles ${ }^{2}$, Nayara Fernanda Siviero Garcia ${ }^{2}$, Daiene Camila Dias \\ Chaves Corsini ${ }^{2}$, Anderson Teruo Takasu ${ }^{2}$
}

${ }^{1}$ São Paulo State University (UNESP), Department of Plant Health, Rural Engineering and Soil, Ilha Solteira, State of São Paulo, Brazil

${ }^{2}$ São Paulo State University (UNESP), Department of Plant Science, Food Technology and Social Economy, Ilha Solteira, State of São Paulo, Brazil

*Corresponding author: amandarperes_agro@yahoo.com.br

\begin{abstract}
The rationalization of water use, the increase in productivity and the reduction of nutrient losses are among the current challenges of agriculture. Recently, the upland rice cultivar BRS Esmeralda with more tolerance to drought was released. Thus, the objective of this study was to evaluate the hydric variation and nitrogen sources in topdressing in upland rice cultivar BRS Esmeralda. The experiment was conducted at the Education and Research Farm of UNESP located in Selvíria, Mato Grosso do Sul (MS) state, in 2013/14 and 2014/15. The experiment was conducted in the field under randomized blocks with a split-plot design with three hydric variations as plots (irrigation with a recommended water depth for rice + rainfall; irrigation with $75 \%$ of the recommended water depth + rainfall; and without irrigation + rainfall) and four nitrogen sources as subplots (urea, ammonium sulfate, urea + sulfate and coated urea) with four replications. The reduction in water availability delayed the flowering and ripening and reduced the production of dry matter of upland rice. There was a decrease in the productivity of rice grains upon decrease in water availability in the year with incidence of dry spell during the reproductive stage. On the other hand, there was no interference of hydric variation on grain yield in the year with a 14-day water deficit during the vegetative stage. Nitrogen sources provided similar rice productivity. In similar environmental conditions of this work, it is recommended to irrigate upland rice when drought periods occur during the reproductive stage with the recommended depth and that $\mathrm{N}$ fertilization in topdressing be carried out with the fertilizer that presents the lowest cost per $\mathrm{kg}$ of $\mathrm{N}$.
\end{abstract}

Keywords: ammonium sulfate; coated urea; grain yield; Oryza sativa L.; sprinkler irrigation.

Abbreviations: AWC_soil available water content; ECA_water evaporation of Class A tank; ETc_Crop evapotranspiration; Kc_crop coefficient; Kp_tank coeficiente; N_nitrogen; S_sulphur

\section{Introduction}

In Brazil, much of the rice is grown in upland ecosystems without irrigation. This crop has a high susceptibility to water stress. In 2010, the area cropped with upland rice was approximately $49 \%$ of the total area of cultivated rice. However, it accounted for only $21 \%$ of the total production (Ferreira and Santiago, 2012; Grisp, 2013) because the average productivity achieved in this system $\left(1,824 \mathrm{~kg} \mathrm{ha}^{-1}\right)$, which is three times lower than that obtained under flood irrigation conditions (Ferreira and Santiago, 2012).

The low productivity of upland rice is mainly because most rainfed crops are located in areas, where the occurrence of dry spells is common during the rainy season (Crusciol et al., 2003a; Crusciol et al., 2003b; Guimarães et al., 2016; Mauad et al., 2011; Rodrigues et al., 2004; Vela et al., 2013). However, such problems can be minimized using supplemental sprinkler irrigation (Stone and Silveira, 2004).
Sprinkler irrigation in upland rice crop has several advantages. It contributes to the stability of the production and provides a higher productivity and a better product quality. It is also possible to use this irrigation for other crops in subsequent harvests (Stone and Silveira, 2004).

The development of drought-tolerant cultivars may be a solution to the water deficit caused by an irregular distribution of rainfall (Guimarães et al., 2016) and to improve the productive potential. According to Lafitte et al. (2006), this is the greatest challenge for plant breeders to combine a high productivity potential of modern rice cultivars with a high tolerance to drought. The BRS Esmeralda was released recently. Its prominent features are an increased tolerance to drought and a high yield potential (Castro et al., 2014).

In addition to water availability and cultivars, nutrients also interfere with rice crops. Among them, nitrogen is one 
of the most limiting nutrient for productivity of rice in the Brazilian Cerrado region (Fageria et al., 2014). Nitrogen is a nutrient easily lost by leaching, volatilization and denitrification. As a result, the efficiency of its use by plants is low, approximately $50-60 \%$ (Kluthcouski et al., 2006). The use of $\mathrm{N}$ sources may significantly increase the efficiency of the use of nitrogen fertilizers and, consequently, the productivity of annual crops such as rice (Fageria et al., 2003). Ammonium sulfate and urea are the two main sources of nitrogen (N) for annual crops in Brazil (Fageria et al., 2014).

An alternative to increase the efficiency of nitrogenous fertilizers is utilization of slow or controlled-release fertilizers to prevent a fast transformation of the $\mathrm{N}$ contained in the fertilizer into forms less stable in the environment (Cantarella, 2007). Among them, there is polymer-coated urea.

The study of hydric variation and nitrogen sources in new rice cultivars tolerant to drought is necessary, because these factors are very important to guarantee productivity and are related to each other. The hydric variation interferes with the availability (release of the nutrients of the fertilizers), in the loss and uptake of nutrients and also development and production of crops. The rice cultivar, being more tolerant to water stress, can be benefited by the use of nitrogen sources of slow or controlled-release under rainfed conditions, because there may be less loss of nitrogen, mainly by volatilization. Thus, the aim of this study was to evaluate the effect of hydric variation and nitrogen sources in upland rice cultivar BRS Esmeralda under Brazilian Cerrado conditions.

\section{Results and discussion}

\section{Climate aspects and irrigation}

By analyzing climate data (Fig $1 \mathrm{~A}$ ), it appears that in the year $2013 / 14$, the average maximum temperature was $33.0^{\circ} \mathrm{C}$, the minimum was $21.0^{\circ} \mathrm{C}$ and the average was $26.4 \circ \mathrm{C}$. The period between 02.01.2014 and 02.12.2014 recorded the highest frequency of high maximum temperatures (reaching $37.7^{\circ} \mathrm{C}$ ) and an average maximum temperature of $36.6^{\circ} \mathrm{C}$, which coincided with the reproductive stage. According to Yoshida (1981), high temperatures caused high percentages of spikelet sterility. If temperatures exceed $35^{\circ} \mathrm{C}$ at anthesis and last longer than one hour, there is a high percentage of spikelet sterility. Satake and Yoshida (1978) argued that the effect of high temperatures on spikelet sterility varies according to cultivar. The average relative humidity was 79.9\% and the period close to 02.02 .2014 presented a lower relative humidity that occurred together with the maximum temperatures and the lack of rain. It is noteworthy that there was a 16 days period of drought during this harvest, from 01.28.2014 to 02.12.2014. There were only three days with less than $1 \mathrm{~mm}$ of rainfall, corresponding to the crop's reproductive stage (Figure $1 \mathrm{~A}$ ).

In the 2014/15 harvest, the average maximum, minimum and average temperatures were $33.0,21.1$ and $26.3^{\circ} \mathrm{C}$, respectively. The maximum temperature of $39.6^{\circ} \mathrm{C}$ was recorded at 01.20.2015. In the period from 01.10.2015 to 01.22.2015, the maximum temperatures were above 35.5 으. This occurred prior to the reproductive stage (approximately 30 days before flowering). The average relative humidity was $83 \%$. In the second cultivation year, there was also a period of 14 days of drought, from 12.27.2014 to 01.09.2015, which corresponded to the crop's vegetative stage.

In the first year, analysis of total volume of water (irrigation + rainfall) per hydric variation in (Table 1 ) showed that the volume of water available to crop was higher than in the second year, but it was poorly distributed, mainly during the reproductive period (Figure 1). The volume of water during the whole crop cycle was appropriate to each hydric variation, since the need for total water for upland rice varied from 600 to $700 \mathrm{~mm}$ (Fornasieri-Filho and Fornasieri, 2006).

\section{Plants development}

The emergence was occurred at seven and six days after sowing in the years 2013/14 and 2014/15, respectively. According to Fageria (1989), under normal soil conditions, rice seeds germinate between 5 and 7 days.

Flowering and ripening occurred at different dates according to the hydric variation imposed by the treatments (Table 2). During the two years of cultivation, we observed that the decrease in water availability increased the number of days until flowering and ripening. Colombari-Filho and Rangel (2015) argued that the rice cycle increases due to stresses caused by water or nutrient deficiency in the soil, and decreases due to a higher light incidence and a higher temperature. Several studies reported an increase in the crop cycle due to water deficit: Crusciol et al. (2003a), Rodrigues et al. (2004), Crusciol et al. (2006), Heinemann and Stone (2009), Terra et al. (2013) and Vela et al. (2013).

\section{Leaf nitrogen content, dry matter, plant height, lodging, number of panicles per $\mathrm{m}^{2}$ and number of spikelets per panicle}

The average data of leaf nitrogen content, dry matter, plant height, lodging, number of panicles per $\mathrm{m}^{2}$ and number of spikelets per panicle are shown in Table 3.

In the 2013/14 harvest, there was a lower leaf $\mathrm{N}$ content in both irrigation depths in relation to the rainfed treatment (Table 3). This can be attributed to the dilution effect, according to which the concentration (content) of nutrients is diluted due to a greater plant growth (Jarrel and Beverly, 1981). This can be confirmed by the data for dry matter of plants, according to which irrigated plants had a higher growth. Moreover, Mauad et al. (2011) found lower leaf nitrogen content with the decrease in water availability. There was no influence of nitrogen sources for this variable. Lopes et al. (2013) and Hernandes et al. (2010), assessed ammonium sulfonitrate with a nitrification inhibitor (Entec), ammonium sulfate and urea and found no differences regarding leaf nitrogen content. There were no differences in the hydric variation and nitrogen sources during the second year.

Cantarella et al. (1997) considered 27-35 g kg ${ }^{-1}$ of nitrogen contents in the leaf as suitable for rice. Thus, for the two harvests, the contents were appropriate and there was no limitation exerted by this nutrient to the growth and development of plants.

The dry matter of plants in the two harvests was influenced by hydric variation (Table 3 ). In the first year, there was a lower dry mass value for rainfed compared to treatments with irrigation. 
Table 1. Accumulated volume of irrigation, rainfall and total water in upland rice crop as function of irrigation depths. Selvíria/MS, 2013/14 and 2014/15.

\begin{tabular}{lll}
\hline Volume of water of the rice crop in 2013/14 & & \\
\hline Hydric Variation & Irrigation (mm) & Rainfall (mm) \\
\hline Recommended & 289 & 665 \\
$75 \%$ of the Recommended & 225 & 735 \\
Rainfed & 0 & 775 \\
\hline Volume of water of the rice crop in 2014/15 & 960 \\
\hline Recommended & 159 & 461 \\
$75 \%$ of the Recommended & 127 & 620 \\
Rainfed & 0 & 606 \\
\hline
\end{tabular}

(A)
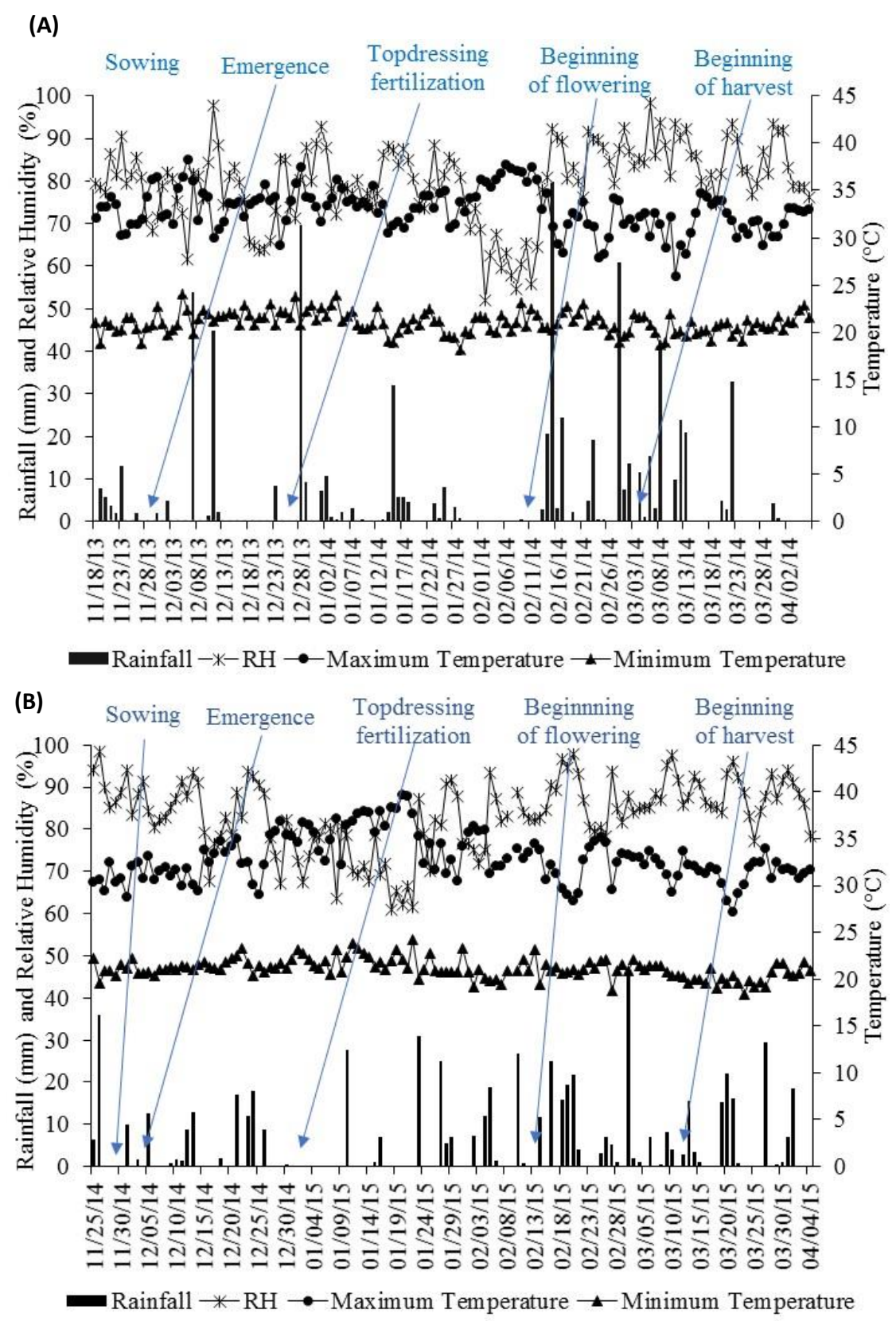

Fig 1. Maximum and minimum temperature, rainfall and relative humidity recorded during the experiment in (A) 2013/14 and (B) 2014/15. Selvíria/MS. 
Table 2. Dates and days after emergence on which the flowering and ripening of upland rice occurred in function of hydric variation in the 2013/14 and 2014/15 harvests. Selvíria/MS.

\begin{tabular}{|c|c|c|c|}
\hline \multirow{2}{*}{ Year } & \multicolumn{3}{|c|}{ Hydric Variation } \\
\hline & Recommended & $75 \%$ of the Recommended & Rainfed \\
\hline \multicolumn{4}{|l|}{ Flowering } \\
\hline $2013 / 14$ & 02.09.2014 (73 DAE) & 02.13.2014 (77 DAE) & 02.28.2014 (92 DAE) \\
\hline $2014 / 15$ & 02.13.2015 (71 DAE) & 02.17.2015 (75 DAE) & 02.27 .2015 (85 DAE) \\
\hline \multicolumn{4}{|c|}{ Ripening (cycle) } \\
\hline $2013 / 14$ & 03.10.2014 (102 DAE) & 03.15.2014 (107 DAE) & 03.29.2014 (121 DAE) \\
\hline $2014 / 15$ & 03.11.2015 (97 DAE) & 03.13.2015 (97 DAE) & 04.01.2015 (118 DAE) \\
\hline
\end{tabular}

Table 3. Average values for leaf nitrogen content (leaf N), dry matter of plants (DM), height (H), lodging (LODG), number of panicles per $\mathrm{m}^{2}$ (PAN) and number of spikelets per panicle (SPIK) in function of hydric variation and nitrogen sources in upland rice. Selvíria/MS, 2013/14 and 2014/15.

\begin{tabular}{|c|c|c|c|c|c|c|c|c|c|c|c|c|}
\hline \multirow[t]{2}{*}{ Treatments } & \multicolumn{2}{|l|}{$\begin{array}{l}\text { Leaf } N \\
\left(\mathrm{~g} \mathrm{~kg}^{-1}\right)\end{array}$} & \multicolumn{2}{|l|}{$\begin{array}{l}\mathrm{DM} \\
\left(\mathrm{kg} \mathrm{ha}^{-1}\right)\end{array}$} & \multicolumn{2}{|l|}{$\begin{array}{l}\mathrm{H} \\
(\mathrm{cm})\end{array}$} & \multicolumn{2}{|l|}{$\begin{array}{l}\text { LODG }^{1} \\
\text { (scores) }\end{array}$} & \multicolumn{2}{|c|}{$\begin{array}{l}\text { PAN } \\
\text { (number } \mathrm{m}^{2} \text { ) }\end{array}$} & \multicolumn{2}{|l|}{$\begin{array}{l}\text { SPIK } \\
\text { (no. } \text { pan }^{-1} \text { ) }\end{array}$} \\
\hline & $2013 / 14$ & $2014 / 15$ & $2013 / 14$ & $2014 / 15$ & $2013 / 14$ & $2014 / 15$ & $2013 / 14$ & $2014 / 15$ & $2013 / 14$ & $2014 / 15$ & $2013 / 14$ & $2014 / 15$ \\
\hline \multicolumn{13}{|l|}{ HYDRIC VARIATION } \\
\hline Recommended & $33.61 \mathrm{~b}$ & 36.52 & $8,727 a$ & $10,950 a$ & $86.83 a$ & $123.92 a$ & 0 & $4.19 a$ & 176.43 & $307.32 \mathrm{a}$ & 130.53 & 130.31 \\
\hline $75 \%$ of the Recommended & $32.14 b$ & 35.66 & $7,798 a$ & $9,529 b$ & $74.77 b$ & $123.40 \mathrm{a}$ & 0 & $2.43 a$ & 158.93 & $319.11 \mathrm{a}$ & 124.81 & 135.56 \\
\hline Rainfed & $39.38 a$ & 34.95 & $6,423 b$ & $7,867 c$ & $80.77 a b$ & $106.23 b$ & 0 & $0.00 \mathrm{~b}$ & 173.75 & $256.61 b$ & 135.82 & 138.87 \\
\hline LSD & 1.54 & 1.82 & 1,159 & 814 & 6.18 & 6.13 & - & 1.90 & 50.91 & 35.23 & 16.59 & 14.58 \\
\hline \multicolumn{13}{|l|}{ NITROGEN SOURCES } \\
\hline Urea & 35.21 & 35.93 & 7,604 & 9,100 & $82.69 a$ & 116.89 & 0 & 2.33 & 173.10 & 287.62 & 131.51 & 138.00 \\
\hline Ammonium sulfate & 34.80 & 35.79 & 7,350 & 9,145 & $80.50 a b$ & 117.61 & 0 & 2.25 & 171.90 & 303.10 & 125.20 & 136.25 \\
\hline Urea + ammonium Sulfate & 34.84 & 35.67 & 7,710 & 10,307 & $78.75 b$ & 118.83 & 0 & 2.58 & 165.71 & 305.71 & 128.96 & 135.73 \\
\hline Coated Urea & 35.33 & 35.45 & 7,934 & 9,243 & $81.22 a b$ & 118.06 & 0 & 1.67 & 168.90 & 280.95 & 135.87 & 129.68 \\
\hline LSD & 1.18 & 0.99 & 1,037 & 1,464 & 3.03 & 4.18 & - & 1.11 & 38.56 & 34.59 & 13.54 & 16.35 \\
\hline \multicolumn{13}{|l|}{$\mathrm{F}$} \\
\hline Blocks (B) & $8.64 *$ & $2.07 \mathrm{~ns}$ & $4.20 \mathrm{~ns}$ & $8.15^{*}$ & $2.40 \mathrm{~ns}$ & $2.31 \mathrm{~ns}$ & - & $2.70 \mathrm{~ns}$ & $4.12 \mathrm{~ns}$ & $6.29 *$ & $2.60 \mathrm{~ns}$ & $1.91 \mathrm{~ns}$ \\
\hline Hydric Variation (HV) & $115.86 * *$ & $4.77 n s$ & $18.84 * *$ & $67.55^{* *}$ & $17.92 * *$ & $50.71 * *$ & - & $12.67 * *$ & $0.65 n s$ & $16.72 * *$ & $2.07 n s$ & $1.64 \mathrm{~ns}$ \\
\hline CV (\%) & 4.05 & 3.50 & 13.97 & 7.95 & 7.06 & 4.80 & - & 54.13 & 27.66 & 11.04 & 11.74 & 9.96 \\
\hline $\mathrm{N}$ sources $(\mathrm{N})$ & $0.75 n s$ & $0.66 n s$ & $0.82 \mathrm{~ns}$ & $2.31 \mathrm{~ns}$ & $4.37^{*}$ & $0.57 \mathrm{~ns}$ & - & $1.51 \mathrm{~ns}$ & $0.12 \mathrm{~ns}$ & $1.80 \mathrm{~ns}$ & $1.64 \mathrm{~ns}$ & $0.73 n s$ \\
\hline $\mathrm{HV} \times \mathrm{N}$ & $1.28 \mathrm{~ns}$ & $0.28 \mathrm{~ns}$ & $0.95 n s$ & $1.19 \mathrm{~ns}$ & $2.33 n s$ & $0.89 n s$ & - & $1.14 \mathrm{~ns}$ & $1.78 \mathrm{~ns}$ & $0.94 n s$ & $2.00 \mathrm{~ns}$ & $0.23 \mathrm{~ns}$ \\
\hline CV (\%) & 3.01 & 2.08 & 12.13 & 13.87 & 3.36 & 3.17 & - & 21.88 & 20.33 & 10.51 & 9.29 & 10.84 \\
\hline Average & 35.04 & 35.71 & 7,649 & 9,449 & 80.79 & 117.85 & 0 & 2.21 & 169.7 & 294.35 & 130.39 & 134.91 \\
\hline
\end{tabular}


Table 4. Average values for spikelet fertility (FERT), weight of 100 grains (W100) and productivity of grains (PROD) in function of hydric variation and nitrogen sources for upland rice. Selvíria/MS, 2013/14 and 2014/15.

\begin{tabular}{|c|c|c|c|c|c|c|}
\hline Treatments & $\begin{array}{l}\text { FERT } \\
(\%) \\
2013 / 14\end{array}$ & $2014 / 15$ & $\begin{array}{l}\text { W100 } \\
\text { (g) } \\
2013 / 14\end{array}$ & $2014 / 15$ & $\begin{array}{l}\text { PROD } \\
\left(\mathrm{kg} \mathrm{ha}^{-1}\right) \\
2013 / 14\end{array}$ & $2014 / 15$ \\
\hline \multicolumn{7}{|l|}{ HYDRIC VARIATION } \\
\hline Recommended & $75.18 a$ & $79.04 b$ & $2.67 a$ & $2.72 b$ & 1,964a & 5,255 \\
\hline $75 \%$ of the Recommended & $51.59 b$ & $83.62 a b$ & $2.59 a$ & $2.71 b$ & $1,373 b$ & 5,408 \\
\hline Rainfed Treatment & $66.04 a b$ & $88.00 a$ & $2.39 \mathrm{~b}$ & $2.83 a$ & $681 c$ & 5,433 \\
\hline LSD & 15.36 & 6.74 & 0.08 & 0.07 & 589 & 749 \\
\hline \multicolumn{7}{|l|}{ NITROGEN SOURCES } \\
\hline Urea & 66.32 & 83.49 & 2.56 & 2.77 & 1,434 & 5,309 \\
\hline Ammonium ammonium sulfate & 60.92 & 82.02 & 2.55 & 2.75 & 1,174 & 5,211 \\
\hline Urea + Sulfate & 62.31 & 83.39 & 2.53 & 2.75 & 1,417 & 5,326 \\
\hline Coated Urea & 67.53 & 85.32 & 2.56 & 2.75 & 1,332 & 5,615 \\
\hline LSD & 11.34 & 4.43 & 0.12 & 0.07 & 470 & 753 \\
\hline \multicolumn{7}{|l|}{$\mathrm{F}$} \\
\hline Blocks & $3.54 \mathrm{~ns}$ & $4.33 \mathrm{~ns}$ & $1.31 \mathrm{~ns}$ & $1.61 \mathrm{~ns}$ & $3.84 \mathrm{~ns}$ & $0.21 \mathrm{~ns}$ \\
\hline Hydric Variation (HV) & $11.28 * *$ & $8.32 *$ & $56.77 * *$ & $15.31 * *$ & $22.10 * *$ & $0.31 \mathrm{~ns}$ \\
\hline CV (\%) & 22.05 & 7.43 & 2.97 & 2.50 & 40.81 & 12.87 \\
\hline$N$ sources $(N)$ & $1.16 \mathrm{~ns}$ & $1.40 \mathrm{~ns}$ & $0.24 \mathrm{~ns}$ & $0.30 \mathrm{~ns}$ & $0.96 \mathrm{~ns}$ & $0.80 \mathrm{~ns}$ \\
\hline $\mathrm{HV} \times \mathrm{N}$ & $1.64 \mathrm{~ns}$ & $2.25 \mathrm{~ns}$ & $0.11 \mathrm{~ns}$ & $0.56 \mathrm{~ns}$ & $2.18 \mathrm{~ns}$ & $0.18 n s$ \\
\hline CV (\%) & 15.80 & 4.75 & 4.11 & 2.34 & 31.42 & 12.55 \\
\hline Average & 64.27 & 83.55 & 2.55 & 2.75 & 1,339 & 5,365 \\
\hline
\end{tabular}

Table 5. Chemical analysis of the soil from the experimental area at the layer 0.00-0.20 m. Selvíria/MS, 2013 and 2014.

\begin{tabular}{|c|c|c|c|c|c|c|c|c|c|c|}
\hline \multirow[b]{2}{*}{ Year } & \multirow{2}{*}{$\begin{array}{c}\text { P resin } \\
\mathrm{mg} \mathrm{dm}^{-3}\end{array}$} & \multirow{2}{*}{$\begin{array}{c}\mathrm{OM} \\
\mathrm{g} \mathrm{dm}^{-3}\end{array}$} & \multirow{2}{*}{$\begin{array}{c}\mathrm{pH} \\
\mathrm{CaCl}_{2}\end{array}$} & $\mathrm{~K}$ & $\mathrm{Ca}$ & $\mathrm{Mg}$ & $\mathrm{H}+\mathrm{Al}$ & $\mathrm{Al}$ & CEC & \multirow{2}{*}{$\begin{array}{l}\text { BS } \\
\%\end{array}$} \\
\hline & & & & \multicolumn{6}{|c|}{$\mathrm{mmol}_{\mathrm{c}} \mathrm{dm}^{-3}$} & \\
\hline 2013 & 29 & 18 & 4.7 & 1.4 & 12 & 8 & 29 & 6 & 50.4 & 42 \\
\hline 2014 & 31 & 16 & 5.6 & 4 & 23 & 19 & 28 & 0 & 74 & 62 \\
\hline
\end{tabular}

Table 6. Crop coefficients $(\mathrm{Kc})$ for the calculation of water replenishment in the various stages of development of upland rice crop.

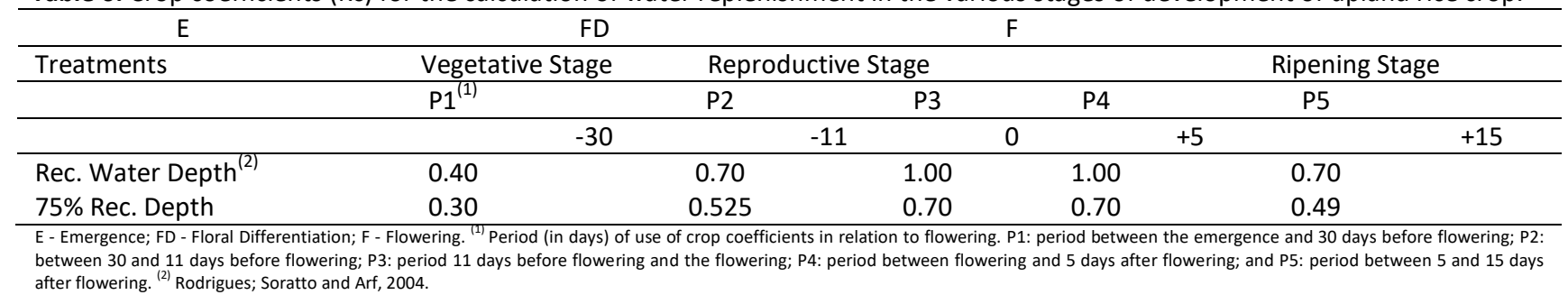

Mauad et al. (2011) also verified a lower production of dry matter with less water availability. In the second year, the highest value for this variable was observed for the recommended depth. The second highest value was observed for the $75 \%$ of the recommended depth and followed by the lower value for the rainfed treatment. In other words, when water availability decreased, the dry matter of plants decreased. Crusciol et al. (2013) reported a lower dry mass of upland rice with the induction of water stress. According to Terra et al. (2013), plants under water deficit decrease their photosynthetic rate, showing consequently negative effects on the production of biomass. In addition, water is related to various processes within the plant, such as cell growth by cell turgor (Mauad et al., 2011).

The plant height, in 2013/14, was influenced by the hydric variation and nitrogen sources (Table 3 ). The highest height was obtained with the recommended depth in relation to the $75 \%$ of the recommended depth, without differences between the rainfed treatment and the depths. This may have occurred because of the high temperatures during the final period of the formation of panicles of irrigated plants, a period that may have coincided with the lengthening of the internodes in the treatment with $75 \%$ of the recommended depth. This event occurs before flowering and the flowering occur one day after that period. According to FornasieriFilho and Fornasieri (2006), temperatures above $30^{\circ} \mathrm{C}$ decreased net photosynthesis due to increased photorespiration and respiration. Thus, it may have contributed to the smaller lengthening of the culms. Yoshida (1981) argued that high temperatures may reduce plant height. Furthermore, according to Yoshida (1981), varietal differences affect tolerance to high temperatures at various 
growth stages, since a variety can be very tolerant to high temperatures in one growth stage but susceptible at other growth stages. As for nitrogen sources, urea provided the greatest height in relation to urea + ammonium sulfate, where the availability of nitrogen from this source may have contributed to a better growth compared to the combination of them. However, it is important to consider that the observed values are very close and coupled with the low coefficient of variation, it is verified that the differences are not sufficient to detect great differences in the performance of rice regarding nitrogen sources.

In the 2014/15 harvest, there was an influence of hydric variation on plant height. Irrigated treatments resulted in higher values (Table 3). Rodrigues et al. (2004); Crusciol et al. (2006) and Artigiani et al. (2012) also verified a smaller plant height in rainfed treatments compared to irrigated treatments. According to Crusciol et al. (2006), this may be explained by the low nutrient absorption, which affects cell division and growth.

In the first harvest, lodging was not observed (Table 3). However, in the second harvest, there was up to $100 \%$ lodging, which may be related to soil fertility. This is because during the second year, rice was grown in a more fertile soil, as shown in Table 5. It was observed that the higher water availability using sprinkler irrigation in the recommended depth and in the $75 \%$ of the recommended depth promoted a higher lodging compared to the rainfed treatment, in which there was no lodging. Crusciol et al. (2006) also verified no lodging in rice grown in rainfed treatments, while, lodging was observed in irrigated rice. Crusciol et al. (2003b), studied effect of irrigation water depths (rainfed, L1 = based on 0.5 of the crop coefficient $(\mathrm{Kc}), \mathrm{L} 2$ = based on the $\mathrm{Kc}$ of the crop, $\mathrm{L} 3=1.5$ of $\mathrm{Kc}$; and $\mathrm{L} 4=1.95$ of $\mathrm{Kc}$ ) on the Caiapó cultivar (traditional group). They observed that the higher height reflected in the highest value for lodging (75$100 \%$ of plants lodged) in the greater water depth (L4), by which the greater water availability induces more lodging in taller cultivars.

The number of panicles per $\mathrm{m}^{-2}$ in the first year of cultivation was not influenced by the hydric variation and nitrogen sources (Table 3). Similarly, Crusciol et al. (2006) reported that the number of panicles per square meter was not influenced by the cultivation system (rainfed and irrigated) in two experimental years. The water availability was not a limiting factor for tillering and for the transformation of vegetative buds into reproductive buds. Artigiani et al. (2012) found no differences between the rice grown in rainfed and irrigated treatments.

In the 2014/15 year, there was a difference among hydric variations, in which the irrigated treatments produced more panicles compared to rainfed treatments. Pinheiro et al. (1985) reported a higher number of panicles per $\mathrm{m}^{-2}$ in the experiment with irrigation in relation to that developed under rainfed conditions. Vela et al. (2013), applied 0, 50, 100,150 and $200 \%$ of evapotranspiration and reported that the treatments with irrigation resonated a quadratic increase in the number of panicles per square meter until the estimated depth consisted of $177 \%$ of evapotranspiration.

The number of spikelets per panicle in the two harvests was not influenced by the evaluated treatments (Table 3 ). Likewise, Crusciol et al. (2003b) found no differences between depths regarding the number of spikelets per panicle, when evaluating the L1 (0.5 time the Kc), L2 (1.0 time the $\mathrm{Kc}), \mathrm{L} 3(1.5$ times the $\mathrm{Kc})$ and $\mathrm{L} 4(\mathrm{Kc}=1.95)$ depths and rainfed treatments with the Caiapó cultivar. The water deficit was occurred during the vegetative stage. Artigiani et al. (2012) also did not observe differences in the amount of spikelets between irrigated and rainfed treatments. Moreover, in the second year, there was lodging with the irrigation depths, which may have resulted in loss of grains, and consequently, in no differences between the depths and the rainfed treatment.

\section{Spikelet fertility, weight of 100 grains and productivity of grains}

Spikelet fertility data were influenced by hydric variations in the two years (Table 4). In 2013/14, the recommended depth provided higher spikelet fertility compared to the $75 \%$ of the recommended depth, and did not differ from the rainfed treatment. This is probably associated with a period with high temperatures linked to a lower water availability in the $75 \%$ of the recommended depth. According to Fageria (1984), when rice is exposed to high temperatures, it reduces the production and the production components, wherein the percentage of full grains is influenced by several factors such as climatic conditions, soil type, nutrient contents and diseases and pests. Moreover, according to Yoshida (1981), the percentage of full spikelets is determined before and after the emergence of the panicle. Unfavorable weather conditions such as low or high temperatures close to the reduction-division and the flowering stages may induce sterility (Yoshida, 1981).

In $2014 / 15$, the highest spikelet fertility occurred in the rainfed treatment in relation to the recommended depth and it was not different from the treatment $75 \%$ of the recommended depth (Table 4). The lower fertility of spikelets on the recommended depth may be related to lodging, since lodging reduces the cross section of vascular bundles; thus, decreasing the movement of photoassimilates and nutrients absorbed by the roots, increasing selfshadowing and contributing to higher grain sterility (Fageria, 1989; Guimarães et al., 2002) and grain loss in the soil (Breseghello et al., 1998). In addition, the rainfed treatment may have benefited from the occurrence of adequate availability of rain during flowering. On the other hand, Crusciol et al. (2006) found spikelets with a higher fertility for cultivation under an irrigated condition compared to rainfed.

The weight of 100 grains in the two harvests was affected by hydric variation (Table 4). In 2013/14, the higher weight of 100 grains was provided by the recommended and $75 \%$ of the recommended depths compared to the rainfed treatment. This allowed observing that as the availability of water reduces there is a decrease in the weight of 100 grains. According to Guimarães et al. (2002), several factors may influence the reduction in the mass of 100 grains of rice during flowering, such as water deficiency, nitrogen deficiency, low solar radiation and blast. Rodrigues et al. (2004) observed that the treatment without irrigation obtained values for weight of 100 grains statistically lower than the other treatments (recommended depth and $50 \%$ of the recommended depth). Vela et al. (2013), studied 
irrigation depths based on the percentage of crop evapotranspiration (ETC) and sprinkler irrigation (L1: without irrigation [control], L2: $50 \%$ of ETC, L3: $100 \%$ of ETc, L4: 150\% of ETC, and L5: $200 \%$ of ETc) in cultivar BEST 2000. They reported that data fitted a quadratic equation. The value for maximum weight of 1,000 grains was $24.05 \mathrm{~g}$, obtained at a depth of $178.62 \%$ of the ETc. Crusciol et al. (2006) verified that grains from the sprinkler irrigation system have a higher mass compared with those from the rainfed system.

In 2014/15, it was observed that the rainfed treatment provided a value for weight of 100 grains higher than the recommended depth and the $75 \%$ of the recommended depth (Table 4). This may be due to lodging in those treatments, for it may have provided a lower grain filling. According to Guimarães et al. (2002), lodging reduces the cross section of the vascular bundles, consequently reducing the movement of photoassimilates and nutrients absorbed by the roots. According to Fonasieri and Fornasieri-Filho (2006), the mass of the grain is determined during the formation and filling periods mainly by the size of the shell, by the number of cells in the endosperm and by the amount of assimilates available to be transported between anthesis and physiological ripening.

The hydric variation resulted in differences in grain yield in 2013/14 (Table 4). There was a decrease in productivity upon decrease in water availability. The highest value was observed for the recommended depth, followed by $75 \%$ of the recommended depth and the rainfed treatment. This may be associated with a lower water availability decreasing the production of dry mass, and consequently, the production of assimilates to fill grains and the weight of 100 grains. Therefore, the reduction in water availability decreased the grain yield by $30 \%$ for the treatment $75 \%$ of the recommended depth and by $65 \%$ for the rainfed treatment in relation to recommended depth. Fageria et al. (2011) reported that the variability in the productivity of rice grains was $89 \%$ due to shoot dry mass. Heinemann et al. (2011) stated that gas exchanges in plant leaves are reduced under drought, leading to less accumulation of biomass and a lower production of grains. Moreover, it is important to note that, the water deficit period occurring during the reproductive stage (Figure $1 \mathrm{~A}$ ) and high temperatures resulted in significant reductions in the potential of rice production.

The beginning of the high-temperature period corresponded to 9,13 and 28 days before flowering in the recommended depth, $75 \%$ of the recommended depth and the rainfed treatment, respectively. It lasted for 12 days, therefore up to 3 days after flowering, and 1 and 16 days before flowering, respectively, contributing to a decreased productivity. By observing the reduced productivity of the recommended depth in 2013/14, which was supposed to have ideal conditions for the development of the crop in relation to the overall average of the following year (2014/15), a reduction of $63 \%$ was observed. It may have been mostly due to high temperatures.

Several studies also reported a decrease in productivity by reducing the volume of water for upland rice crops. Pinheiro et al. (2006) observed losses in productivity under water stress close to the period of $50 \%$ flowering in many cultivars of rice. Cancellier et al. (2011) obtained low productivities in an experiment developed with upland rice in the municipality of Gurupi, Tocantins state. They attributed the low yield to the water stress that occurred from the differentiation stage of flower primordia, in which such stress resulted in a high spikelet sterility, further potentialized by the high temperatures, which occurred at that time (exceeding $35^{\circ} \mathrm{C}$ ). Plus, the drought was prolonged, and intensified the panicle emission stage, also damaging the grain filling stage.

In the second year, there was no interference of irrigation levels on productivity, which can be related to a good rainfall at flowering and to grain filling in addition to the water deficit which occurred during the crop's vegetative stage. The absence of difference between the depths for the cultivar BRS Esmeralda may also be related to lodging, whereas in irrigation depths a better development was noted at rainfed treatment. Because of the lodging, there was grain fall in the field. A work by O'Toole and Moya (1981) also reported a relative lack of sensitivity to water stress during vegetative stage, and a high sensitivity during the reproductive stage. All crops that were under water deficit during the vegetative stage had a fair production despite the high level and the duration of the drought (O'Toole and Moya, 1981). On the other hand, when the deficit occurred during the reproductive stage, the sensitivity characteristic to water deficit was observed. The main characteristic in decreased productivity was due to the increased panicle sterility and the decrease in grain weight. Colombari-Filho and Rangel (2015) stated that when there is some adversity in the crop during the vegetative stage, the rice cycle may be longer, enabling the recovery of plants. In contrary, if the adversity occurs during the reproductive and grain ripening stages, plants will have less chance of recovery from stresses. Yoshida (1981) reports that water stress, at any growth stage, may reduce yield. The rice plant is more sensitive to water deficit from the stage of reduction-division until anthesis. At three days of drought in 11 days and 3 days before anthesis, the yield is reduced significantly, causing a high percentage of sterility. If sterility occurs, there is no way to compensate it. On the other hand, water stress during the growing season may reduce plant height, number of tillers and leaf area, but the yield will not be affected by the delayed growth if water is supplied in sufficient time to allow a recovery before flowering (Yoshida, 1981).

The evaluated nitrogen sources did not affect grain yield in the two years of cultivation (Table 4). Probably, the absence of difference among nitrogen sources, particularly the coated fertilizer, may be related to the high temperatures that occurred during the experiment, which is common in the Cerrado region. According to IPNI (no publication year), this may be because many coated fertilizers release nutrients faster with the increase of moisture and soil temperature. Several studies show the absence of differences among different nitrogen sources regarding crop productivity. Lopes et al. (2013) and Hernandes et al. (2010), analyzed the influence of urea, ammonium sulfate and ammonium sulfonitrate sources with a nitrification inhibitor on productivity of upland rice irrigated by sprinkling and observed no differences among them. 


\section{Materials and Methods}

\section{Description of the area: location, soil and climate}

The experiment was developed during the 2013/14 and $2014 / 15$ harvest seasons in the experimental area of the Teaching, Research and Extension Farm at the Engineering Faculty of UNESP, Ilha Solteira, located in Selvíria/MS. Its geographical coordinates are approximately $51^{\circ} 24^{\prime} \mathrm{W}$ and $20^{\circ} 20^{\prime} \mathrm{S}$. The altitude is 340 meters. The soil of the area is a Dystrophic RED LATOSOL (Oxisol) with a clayey texture according to the classification of Santos et al. (2013).

Before the experiment, soil samples of the area were collected at the layer $0.00-0.20 \mathrm{~m}$ for chemical analysis according to the methodology described by Raij et al. (2001). The soil characteristics are shown in Table 5 . According to the Köppen classification, the climate of the region is Aw: humid tropical, rainy in the summer and dry in the winter. The average annual rainfall is $1,313 \mathrm{~mm}$. The average annual of minimum temperature is $19^{\circ} \mathrm{C}$, the maximum is $31^{\circ} \mathrm{C}$ and the average is $25^{\circ} \mathrm{C}$ (Portugal et al., 2015).

The minimum and maximum temperature, rainfall and relative humidity recorded during the experiment were obtained from the agro-meteorological station located near the experimental area (Figure 1).

\section{Experimental design and treatments}

The experimental design consisted of randomized blocks with 12 treatments arranged in a split-plot design with four replications to evaluate three hydric variations as plots (1) Irrigation with the recommended water depth + rainfall, "Recommended"; (2) Irrigation with $75 \%$ of the recommended water depth + rainfall, "75\% of the recommended"; (3) No irrigation + rainfall, "Rainfed" and four nitrogen sources as subplots (urea, ammonium sulfate, urea + ammonium sulfate and polymer-coated urea).

The plots consisted of 5 rows, $5 \mathrm{~m}$ in length each. The useful area had three central rows, in which $0.50 \mathrm{~m}$ at both extremities were ignored.

\section{Plant material}

The cultivar BRS Esmeralda has main characteristics such as high productivity, vigorous plants with a good architecture, delayed senescence ("stay green") (Castro et al., 2014), increased tolerance to drought stress and hardiness (Embrapa, 2013). The plant height is usually between 95 and $108 \mathrm{~cm}$. The average sowing-to-flowering cycle is 77 days (Castro et al., 2014) and the total cycle is between 105 and 110 days (Embrapa, 2013).

\section{Nitrogen sources}

Urea $\left(\left(\mathrm{NH}_{2}\right)_{2} \mathrm{CO}\right)$ is the most concentrated form of solid nitrogen fertilizer available, which contains $46 \%$ nitrogen. It is formed by the reaction of ammonia with carbon dioxide $\left(2 \mathrm{NH}_{3}+\mathrm{CO}_{2}\right)$ (Troeh and Thompson, 2007).

Ammonium sulfate $\left(\left(\mathrm{NH}_{4}\right)_{2} \mathrm{SO}_{4}\right)$ is produced from ammonia by reaction with sulfuric acid $\left(2 \mathrm{NH}_{3}+\mathrm{H}_{2} \mathrm{SO}_{4}\right)$. It contains $21 \%$ nitrogen and 24\% sulfur (Troeh and Thompson, 2007).
The addition of polymers in the envelope layer of fertilizer can alter the release characteristics of nutrients to approximate crop needs (Troeh and Thompson, 2007). The Kimberlit company, based in Olímpia, Sao Paulo state in Brazil, has developed a new technology called Kimcoat ${ }^{\circledR}$. This technology is composed of three layers of additives (polymers) that protect the nitrogen fertilizer (urea) from the main losses that occur in the fertilization process, such as volatilization, nitrification and denitrification (Reis-Júnior, 2007). This polymer-coated urea (Kimcoat) has $43 \%$ nitrogen.

\section{Irrigation}

The irrigation of rice was performed using a fixed conventional sprinkler system with an average precipitation of $3.3 \mathrm{~mm} \mathrm{~h}^{-1}$, operating pressure of $0.25 \mathrm{MPa}$ and a $6 \mathrm{~m} \times 6$ $\mathrm{m}$ spacing between sprinklers.

The volume of water to be irrigated was determined using the class A tank method, in which water evaporation (ECA) was daily obtained from a Class A tank installed at the Meteorological Station close to the experimental area. The Class A tank coefficient (Kp) was used as proposed by Doorenbos and Pruitt (1976), which takes the surrounding area, wind speed and relative humidity into account.

In the water management, for the recommended depth, the crop coefficients $\left(\mathrm{Kc}_{\mathrm{s}}\right)$ proposed by Rodrigues et al. (2004) were used; for the $75 \%$ of the recommended depth, $\mathrm{Kc}_{\mathrm{s}}$ were calculated from the $\mathrm{Kc}_{\mathrm{s}}$ of the recommended depth (Table 6). The water supply was performed when the accumulated crop evapotranspiration (ETc) reached values close to soil available water content (AWC).

\section{Installation and conducting of field experiment}

The preparation of the area was made using a chisel plow, followed by two harrowing using a light harrow. This was done to harrow and level the ground in two years of cultivation. The last harrowing was performed at the eve of the sowing.

The sowing of rice was performed mechanically on 11.21.2013 in the first year and on 11.28.2014 in the second year using a row spacing of $0.35 \mathrm{~m}$ and an amount of seeds sufficient to obtain 230 plants $\mathrm{m}^{-2}\left(70 \mathrm{~kg} \mathrm{ha}^{-1}\right)$.

The basic mineral fertilizer in the sowing furrows was calculated according to the chemical characteristics of the soil (Table 5) and considered the recommendations by Cantarella et al. (1997) aiming a productivity of 3.0-4.0 $\mathrm{tha}^{-1}$. In the 2013/14 harvest, $300 \mathrm{~kg} \mathrm{ha}^{-1}$ of the formulation 4-14-8 (with $11.82 \%$ S) was used. In the $2014 / 15$ harvest, $150 \mathrm{~kg}$ ha ${ }^{1}$ of the formulation 8-28-16 (with $4.24 \%$ S) was used.

The nitrogen fertilization in topdressing was performed at 29 days after emergence (DAE) (12.27.2013) and at 30 DAE (01.03.2015) in the first and the second year, respectively, on the soil surface (between the crop rows) using $60 \mathrm{~kg} \mathrm{ha}^{-1}$ of $\mathrm{N}$. Regarding the sources used, urea had $46 \%$ of $\mathrm{N}$, polymer-coated urea (Kimcoat ${ }^{\circ}$ ) contained $43 \%$ of nitrogen and ammonium sulfate had $20 \%$ of nitrogen. Regarding the treatment with the combination of urea + ammonium sulfate, $50 \%$ of the dose was applied as urea (corresponding to $30 \mathrm{~kg} \mathrm{ha}^{-1}$ of $\mathrm{N}$ ) and the other $50 \%$ of the dose as ammonium sulfate (also corresponding to $30 \mathrm{~kg} \mathrm{ha}^{-1} \mathrm{~N}$ ). The 
application of nitrogen in topdressing was performed based on probability of rainfall shortly after application of the nitrogen fertilizer, simulating the practical conditions of farmers.

The control of pests, weeds and diseases was performed according to the needs of the crop.

The harvest of rice was manually performed using cleavers to cut plants at the height of the panicles, when in $90 \%$ of panicles, the grains of the upper two thirds of the panicles became hard and the grains from the lower third mediumhard.

\section{Variables analyzed}

The following variables were analyzed: seedling emergence, flowering, ripening (cycle), leaf nitrogen content, dry matter of rice plants, plant height, degree of lodging (visual observations during the ripening stage, using the following score scale: 0 - no lodging; 1 - up to 5\%, 2 - 5-25\%, 3 - 25$50 \%, 4-50-75 \%$, and $5-75-100 \%$ of lodged plants), number of panicles per square meter, number of spikelets per panicle, spikelet fertility, weight of 100 grains and grain yield (corrected to $13 \%$ moisture, wet basis).

\section{Statistical analysis}

Data were evaluated by analysis of variance using the F-test. When the F-value was significant at $5 \%$ probability, the Tukey test was applied to compare means using the statistical software SISVAR (Ferreira, 2011).

\section{Conclusion}

In the year with dry spell and high temperatures during the reproductive stage, there was a decrease in BRS Esmeralda rice grain yield upon decrease in water availability. The 14day water deficit during the vegetative stage did not affect the grains yield of BRS Esmeralda. Nitrogen sources (urea, ammonium sulfate, urea + ammonium sulfate and coated urea) provided similar leaf nitrogen content, dry matter of plants, production components and grain yield of upland rice grown in a rainfed condition or with sprinkler irrigation.

\section{Acknowledgement}

The authors thank to the Embrapa Arroz e Feijão for providing the seeds of cultivar BRS Esmeralda and the Coordenação de Aperfeiçoamento de Pessoal de Nível Superior (CAPES) for the scholarship granted the first author.

\section{References}

Artigiani ACCA, Crusciol CAC, Arf O, Alvarez RCF, Nascente AS (2012) Produtividade e qualidade industrial do arroz de terras altas em função da disponibilidade hídrica e adubação. Pesq Agrop Trop. 42(3): 340-349.

Breseghello F, Castro EM, Morais OP (1998) Cultivares de arroz. In: Breseghello F, Stone L F (eds) Tecnologia para o arroz de terras altas. Embrapa Arroz e Feijão, Santo Antônio de Goiás. cap.7. p.41-53.
Cancellier EL, Barros HB, Kischel E, Gonzaga LAM, Brandão DR, Fidelis RR (2011) Eficiência agronômica no uso de nitrogênio mineral por cultivares de arroz de terras altas. Rev Bras Ciênc Agrár. 6(4): 650-656.

Cantarella H, Raij BV, Camargo CEO (1997) Cereais. In: Raij BV, Cantarella H, Quaggio JA, Furlani AMC (eds) Recomendações de adubação e calagem para o Estado de São Paulo, 2nd edn. Instituto Agronômico de Campinas/Fundação IAC, Campinas. p.43-73.

Cantarella H (2007) Nitrogênio. In: Novais RF, Alvarez VVH, Barros NF, Fontes RLF, Cantarutti RB, Neves JCL (eds) Fertilidade do solo. Sociedade Brasileira de Ciência do Solo, Viçosa. p.375-470.

Castro AP, Morais OP, Breseghello F, Lobo VLS, Guimarães $\mathrm{CM}$, Bassinello PZ, Colombari Filho JM, Santiago CM, Furtini IV, Torga PP, Utumi MM, Pereira JA, Cordeiro ACC, Azevedo R, Sousa NRG, Soares AA, Radmann V, Peters VJ (2014) BRS Esmeralda: cultivar de arroz de terras altas com elevada produtividade e maior tolerância à seca. Embrapa Arroz e Feijão, Santo Antônio de Goiás. 4p. (Comunicado Técnico, 215).

Colombari Filho JM, Rangel PHN (2015) Cultivares. In: Borém A, Rangel PHN (eds) Arroz: do plantio à colheita. Ed. UFV, Viçosa, Cap.5. p.84-121.

Crusciol CAC, Arf O, Soratto RP, Andreotti M (2003a) Produtividade do arroz de terras altas sob condições de sequeiro e irrigado por aspersão em função do espaçamento entre fileiras. Agron. 37(1):10-15.

Crusciol CAC, Arf O, Soratto RP, Andreotti M, Rodrigues RAF (2003b) Produtividade e qualidade industrial de grãos de arroz de terras altas em função de lâminas de água no sistema irrigado por aspersão. Acta Sci Agron. 25(1):125130.

Crusciol CAC, Soratto RP, Arf O, Mateus GP (2006) Yield of upland rice cultivars in rainfed and sprinkler-irrigated systems in the Cerrado region of Brazil. Aust J Exp Agri. 46(11):1515-1520.

Crusciol CAC, Soratto RP, Nascente AS, Arf O (2013) Root distribution, nutriente uptake and yiel of two upland rice cultivars under two water regimes. Agron J. 105(1): $237-$ 247.

Doorenbos J, Pruitt WO (1976) Las necesidades de agua de los cultivos. FAO, Roma. 193 p.

Empresa Brasileira de Pesquisa Agropecuária - Embrapa (2013) BRS Esmeralda: arroz de terras altas. Embrapa Arroz e Feijão, Santo Antônio de Goiás. 2p. (Folder). Avaliable <http://www.infoteca.cnptia.embrapa.br/handle/doc/955 545> Acess in: November, 26, 2015.

Fageria NK (1984) Adubação e nutrição mineral da cultura de arroz. Campus, Rio de Janeiro; Embrapa, Goiânia. 341 p.

Fageria NK (1989) Solos tropicais e aspectos fisiológicos das culturas. EMBRAPA-DPU, Brasília. 425p.

Fageria NK, Slaton NA, Baligar VC (2003) Nutrient management for improving lowland rice productivity and sustainability. Advan Agron. 80: 63-152.

Fageria NK, Moreira A, Coelho AM (2011) Yield and yield components of upland rice as influenced by nitrogen sources. J Plant Nutr. 34(3): 361-370.

Fageria, N. K, Moreira A, Moraes LAC, Moraes MF (2014) Nitrogen uptake and use efficiency in upland rice under 
two nitrogen sources. Commun Soil Sci Plant Anal. 45(4):461-469.

Ferreira DF (2011) SISVAR: a computer statistical analysis system. Ciênc Agrotec. 35(6):1039-1042.

Ferreira CM, Santiago CM (2012) Informações técnicas sobre o arroz de terras altas: estados de Mato Grosso e Rondônia - safras 2010/2011 e 2011/2012. Embrapa Arroz e Feijão, Santo Antônio de Goiás. 112 p. (Documentos 268)

Fornasieri-Filho D, Fornasieri JL (2006) Manual da cultura do arroz. Funep, Jaboticabal. 589 p.

Global Rice Science Partnership - GriSP (2013) Rice almanac, 4th edn. International Rice Research Institute, Los Baños, $283 \mathrm{p}$.

Guimarães CM, Fageria NK, Barbosa Filho MP (2002) Como a planta de arroz se desenvolve. Potafos, Piracicaba. 12 p. (Encarte do Informações Agronômicas n.99, Arquivo do Agronômo n. 13)

Guimarães CM, Castro AP, Stone LF, Oliveira JP (2016) Drought tolerance in upland rice: identification of genotypes and agronomic characteristics. Acta Sci Agron. 38(2):201-206, 2016.

Heinemann AB, Stone LF (2009) Efeito da deficiência hídrica no desenvolvimento e rendimento de quatro cultivares de arroz de terras altas. Pesq Agropec Trop. 39(2):134-139.

Heinemann AB, Stone LF, Fageria NK (2011) Transpiration rate response to water deficit during vegetative and reprodutive phases of upland rice cultivars. Sci Agric. 68(1):24-30.

Hernandes A, Buzetti S, Andreotti M, Arf O, Sá ME (2010) Doses, fontes e épocas de aplicação de nitrogênio em cultivares de arroz. Ciênc Agrotec. 34(2):307-312.

International Plant Nutrition Institute - IPNI. Nutrient source specifics: Coated fertilizer. Avaliable in: <http://www.ipni.net/publication/nss.nsf/0/33C6A283CC3 8EE26852579AF007682E3/\$FILE/NSS-

20\%20Coated\%20Fertilizer.pdf > Acess in: April, 08, 2016.

Jarrel WM, Beverly RB (1981) The dilution effect in plant nutrition studies. Advan Agron. 34:197-224.

Kluthcouski J, Aidar H, Thung M, Oliveira FRA, Cobucci T (2006) Manejo antecipado do nitrogênio nas principais culturas anuais. Embrapa Arroz e Feijão, Santo Antônio de Goiás. 63 p. (Documentos 188).

Lafitte HR, Li ZK, Vijayakumar CHM, Gao YM, Shi Y, Xu JL, Fu BY, Ali AJ, Domingo J, Maghirang R, Torres R, Mackill D (2006) Improvement of rice drought tolerance through backcross breeding: Evaluation of donors and selection in drought nurseries. Field Crops Res. 97(1):77-86.

Lopes RA, Buzetti S, Teixeira Filho MCM, Benetti CGS, Arf MV (2013) Doses, fontes e épocas de aplicação de nitrogênio em arroz de terras altas cultivado em sistema de semeadura direta. Rev Caat. 26(4):79-87.

Mauad M, Crusciol CAC, Grassi Filho H (2011) Produção de massa seca e nutrição de arroz de terras altas sob condição de déficit hídrico e adubação silicatada. Semina: Ciênc Agrár. 32(3):939-948.

O'Toole JC, Moya TB (1981) Water déficits and yield in upland rice. Field Crops Res. 4: 247-259.
Pinheiro BS, Steinmetz S, Stone LF, Guimarães EP (1985) Tipo de planta, regime hídrico e produtividade do arroz de sequeiro. Pesq Agropec Bras. 20(1):87-95.

Pinheiro BS, Castro EM, Guimarães CM (2006) Sustainability and profitability of aerobic rice production in Brazil. Field Crops Res. 97(1):34-42.

Portugal JR, Peres AR, Rodrigues RAF (2015) Aspectos climáticos no feijoeiro. In: Arf $\mathrm{O}$, Lemos LB, Soratto RP, Ferrari $S$ (eds) Aspectos gerais da cultura do feijão Phaseolus vulgaris L. Fepaf, Botucatu. p. 65-75.

Raij BV, Andrade JC, Cantarella H, Quaggio JA (2001) Análise química para avaliação da fertilidade de solos tropicais. Instituto Agronômico, Campinas. 285p.

Reis-Júnior RA (2007) Kimcoat N - Uma nova ferramenta para a otimização do uso de fertilizantes. Inf Agron. 117: 13-14.

Rodrigues RAF, Soratto RP, ARF O (2004) Manejo de água em arroz de terras altas no sistema de plantio direto, usando o tanque classe A. Eng Agríc. 24(3):546-556.

Santos HG, Jacomine PKT, Oliveira VA, Lumbreras JF, Coelho MR, Almeida JA, Cunha TJF, Oliveira JB (2013) Sistema brasileiro de classificação de solos. 3. ed. Embrapa, Brasília. 353p.

Satake T, Yoshida S (1978) High temperature induced sterility in indica rices at flowering. Jap J Crop Sci. 47(1):617.

Stone LF, Silveira PM (2004) Arroz irrigado por aspersão. Embrapa, Santo Antônio de Goiás. 6p. (Circular Técnica, 64)

Terra TGR, Leal TCAB, Borém A, Rangel PHN (2013) Tolerância de linhagens de arroz de terras altas à seca. Pesq Agropec Trop. 43(2):201-208.

Troeh FR, Thompson LM (2007) Solos e fertilidade, 6th edn. Andrei, São Paulo. 718 p.

Vela RHN, Dallacort R, Dalchiavon FC, Araújo DV, Barbieri JD, Kolling EM (2013) Lâminas de irrigação na cultura do arroz de terras altas, no Médio norte do estado de mato grosso. Enc Bios. 9(17):1753-1764.

Yoshida S (1981) Fundamentals of rice crop Science. IRRI, Los Baños. 269p. 